Volume 02 Nomor 01, Juni 2020 Page 17-25

Incrementapedia: Jurnal Pendidikan Anak Usia Dini

Program Studi PG-PAUD Fakultas Pedagogik dan Psikologi

Universitas PGRI Adi Buana Surabaya

http://jurnal.unipasby.ac.id/index.php/incrementapedia

e-ISSN: 2686-3146

\title{
MENGEMBANGKAN KEMAMPUAN MENULIS AWAL ANAK USIA DINI DENGAN MEDIA PUZZLE
}

\author{
Anita Bella Prastiyanti a, Ahmad Fachrurrazi ${ }^{\text {b }}$ \\ a,bPG-PAUD, Fakultas Pedagogik dan Psikologi Universitas PGRI Adi Buana Surabaya \\ bellajune99@gmail.com, ahmadfachrurrazi@unipasby.ac.id
}

\begin{abstract}
Now the initial writing activities at school need to be developed and modified again to attract early childhood interest in early writing activities through media puzzle. Early writing skills have a very important role in literacy recognition. The purpose of this study is to find out and describe more deeply and comprehensively about the effect of puzzle media on the early writing ability of group B TK Agripina Surabaya. The method used in this study is a quantitative research method using the One Group Pretest - Postest design. The sample used was all students of Group B TK Agripina with a total of 20. Data were collected from the results of observations of performance tests, with instrument performance observation sheets. Data analysis techniques using the t test formula. The results showed that the calculated value $t=8.40$ is greater than the value of t table (1.72913) at the 0.05 significance level and (2.53948) at the 0.01 significance level, then the null hypothesis was rejected so that the working hypothesis was accepted. This shows the Working Hypothesis proved to be very significant. Thus it can be stated that "Media Puzzle has a very significant effect on the early writing ability of Group B TK Agripina Surabaya".
\end{abstract}

Keywords: Media Puzzle, Early Writing Ability.

\section{PENDAHULUAN}

Halimah (2016:2) berpendapat bahwa anak usia dini merupakan individu yang berbeda, unik, dan memiliki karakteristik tersendiri sesuai dengan tahapan usianya.

Undang-Undang Nomor 20 Tahun 2003 (dalam Dewi dan Fachrurazi, 2014:2) tentang Sistem Pendidikan Nasional menegaskan bahwa anak usia dini adalah individu dengan usia sejak lahir hingga usia 6 tahun.

Menurut Mulyasa (2014:16) anak usia dini sering disebut anak prasekolah, memiliki masa peka dalam perkembangannya, dan terjadi pematangan fungsi-fungsi fisik dan psikis yang siap merespon berbagai rangsangan dari lingkungannya. Masa ini merupakan saat yang paling tepat untuk meletakkan dasar pertama dan utama dalam mengembangkan berbagai potensi dan kemampuan fisik, kognitif, bahasa, seni, sosial emosional, spiritual, konsep diri, disiplin diri, dan kemandirian.

Anak usia dini merupakan individu dengan usia sejak lahir hingga 6 tahun yang memiliki karakteristik tersendiri, dan unik. Masa usia dini merupakan masa yang sangat penting dan merupakan dasar bagi keberhasilan anak di masa yang akan datang. Masa usia dini merupakan waktu yang sangat tepat untuk memberikan rangsangan pendidikan terutama dalam mengembangkan berbagai potensi yang dimiliki anak.

Mengacu kepada undang-undang Sistem Pendidikan Nasional Tahun 2003 (dalam Mulyani, 2016:12), pengertian pendidikan anak usia dini (PAUD) adalah suatu upaya pembinaan 
yang ditujukan kepada anak sejak lahir sampai dengan usia enam tahun yang dilakukan melalui pemberian rangsangan pendidikan untuk membantu pertumbuhan dan perkembangan jasmani dan rohani, agar anak mempunyai kesiapan dalam memasuki pendidikan lebih lanjut.

Pernyataan tersebut didukung oleh pendapat Mansur (dalam Madyawati, 2017:2) yang menyatakan pendidikan anak usia dini merupakan salah satu bentuk penyelenggaraan pendidikan yang menitik beratkan pada peletakkan dasar ke arah pertumbuhan dan enam perkembangan yaitu: perkembangan moral dan agama, perkembangan fisik (koordinasi motorik kasar dan halus), kecerdasan/ kognitif (daya pikir/daya cipta), sosio-emosional (sikap dan emosi), bahasa, dan komunikasi, sesuai dengan keunikan dan tahap-tahap perkembangan sesuai kelompok usia yang dilalui oleh anak usia dini.

Atas dasar penjelasan para ahli di atas terkait dengan PAUD maka dapat disimpulkan bahwa PAUD merupakan salah satu jenjang pendidikan yang ditujukan bagi anak usia pra sekolah yang berupaya memberikan layanan pendidikan untuk mengoptimalkan pertumbuhan dan perkembangan anak secara menyeluruh yang mencukup seluruh aspek perkembangan anak agar anak siap untuk memasuki jenjang pendidikan selanjutnya.

Sesuai dengan Permendiknas No. 137 tahun 2014 tentang Standar Nasional Pendidikan Anak Usia Dini, bahwa lingkup perkembangan anak mencakup 6 aspek perkembangan yaitu nilai agama dan moral, fisik motorik, kognitif, sosial emosional, seni dan bahasa.
Berkaitan dengan perkembangan kemampuan berbahasa, Mulyasa (2014:116) menyatakan bahasa adalah kemampuan untuk mengekspresikan apa yang dialami dan dipikirkan oleh anak dan kemampuan untuk menangkap pesan dari lawan bicara.

Sementara Bredekamp \& Copple (dalam Madyawati, 2017:41) menjelaskan pengertian perkembangan bahasa meliputi juga perkembangan kompetensi komunikasi, yakni kemampuan untuk menggunakan semua keterampilan berbahasa manusia untuk berekspresi dan memaknai.

Berdasarkan paparan di atas terkait dengan bahasa maka dapat disimpulkan bahasa merupakan kemampuan untuk berkomunikasi dalam mengekspresikan ide/gagasan atau perasaan seseorang.

Saat ini banyak sekali cara untuk mengembangkan bahasa pada anak usia dini. Salah satunya adalah aplikasi mengenalkan huruf dan membaca yang ada pada gadget. Semakin berkembang teknologi, kualitas pendidikan juga semakin maju. Banyak program-program pendidikan yang disediakan untuk anak usia dini yang sudah tentu sangat menarik dan menyenangkan bagi anak.

Program-program tersebut dirancang untuk meningkatkan perkembangan bahasa anak diantaranya dengan bermain melalui gadget anak diajarkan untuk mengenal huruf, menambah kosa kata, mencocokkan kata dengan gambar, dan lain sebagainya. Namun kekurangan dari penggunaan gadget tersebut ialah tidak ada program untuk melatih anak menulis. Pada dasarnya perkembangan bahasa 
tidak hanya meliputi pengenalan huruf dan membaca saja tetapi juga menulis.

Menurut Mulyati (2014:1.10) sehubungan dengan penggunaan bahasa, terdapat empat keterampilan dasar berbahasa, yaitu mendengarkan (menyimak), berbicara, membaca, dan menulis.

Lebih lanjut, Gunarti, dkk (2015:7.10) mengemukakan bahwa anak usia 3 sampai 6 tahun, pada umumnya masa peka anak untuk menulis muncul diawali dengan kesenangan anak untuk mencoret-coret dinding sebagai permukaan untuk menulis.

Menulis di taman kanak-kanak menurut High Scope Child Obsevation Record (dalam Susanto, 2014:91) disebut menulis dini atau menulis awal. Kegiatan menulis dini mencakup anak mencoba teknik menulis menggunakan lekuk-lekuk dan garis sebagai huruf, meniru tulisan atau meniru huruf-huruf yang dapat dikenal, menulis nama sendiri, menulis beberapa kata atau frasa pendek, menulis frasa atau kalimat bervariasi.

Masnipal (2018:238) menyatakan pengajaran membaca, menulis, dan berhitung pada pendidikan anak usia dini dalam beberapa tahun terakhir cenderung meningkat. Pemerintah telah melarang pengajaran langsung calistung di taman kanak-kanak dan sejak dulu guru jarang mengajarkan calistung secara langsung kepada anak didik, kecuali hanya bersifat mengenalkan huruf atau angka. Jika dilaksanakan dengan prinsip yang benar, kegiatan prabaca, pranulis, dan prahitung di taman kanak-kanak bagi anak usia 4-6 tahun tidak perlu ditakutkan. Selain itu Masnipal juga menambahkan bahwa keinginan atau minat anak terhadap kegiatan membaca dan menulis sudah muncul bahkan sebelum umur 56 tahun. Ditinjau dari sudut pandangan kebutuhan perkembangan anak, beralasan jika kegiatan membaca, menulis dan berhitung permulaan dapat diberikan kepada anak usia 5-6 tahun (kelompok B taman kanak-kanak) dengan syarat minimal:

1. Bersifat bermain,

2. Dikemas menarik, asyik, menyenangkan dan anak senang melakukannya,

3. Menggunakan alat permainan/ alat peraga yang menarik,

4. Dilakukan berkelompok/ bukan secara indiviu,

5. Dibimbing oleh guru professional.

Sehubungan dengan pendapat Masnipal, Dhieni (2015:11.26) menjelaskan kegiatan menulis untuk anak harus memperhatikan kesiapan dan kematangan anak. Kegiatan tersebut dapat dilakukan jika perkembangan motorik halus anak telah matang yang terlihat dari kemampuannya dalam memegang pensil. Pada awalnya anak hanya memegang pensil untuk mencoret-coret, namun seiring perkembangannya anak akan mengkonsentrasikan jari-jarinya untuk menulis lebih baik.

Berdasarkan uraian di atas dapat ditarik satu kesimpulan bahwa kemampuan menulis awal merupakan kemampuan dimana anak mengenal tulisan melalui kegiatan-kegiatan sederhana seperti membuat goresan, lekukan, huruf, dan nama sendiri untuk mengungkapkan, dan mengekspresikan diri serta menyampaikan ide atau perasaannya. 
Kegiatan menulis awal ini perlu diperhatikan secara teliti, disesuaikan dengan tahap perkembangan anak dan kesiapan anak termasuk kesiapan motorik halusnya. Kondisi yang ideal untuk mengenalkan menulis awal ini yaitu pada anak TK kelompok B, dimana pada usia kelompok B anak sudah dapat memegang pensil, selain itu kelompok B juga merupakan kelompok yang berada pada masa persiapan untuk memasuki jenjang pendidikan berikutnya (kelas awal sekolah dasar). Dengan demikian mengenalkan menulis awal pada anak kelompok $B$ adalah saat yang sangat tepat. Oleh karena itu keterampilan menulis pada anak usia dini perlu diasah dan dikembangkan lagi melalui kegiatan yang menyenangkan. Karena pada dasarnya prinsip pembelajaran anak usia dini adalah belajar melalui bermain. Dengan begitu keterampilan anak dalam menulis semakin baik, anak juga merasa senang dalam melakukan kegiatan menulis tersebut.

Namun banyak sekali di beberapa Taman Kanak-Kanak yang tidak menerapkan prinsipprinsip PAUD tersebut, salah satunya prinsip belajar melalui bermain. Dimana dalam kegiatan keterampilan menulis, anak hanya diberi tugas untuk menulis huruf atau menebali huruf sesuai contohnya. Namun tidak ada unsur permainan di dalamnya. Sehingga pembelajaran menjadi kurang berkesan bagi anak.

Dari pengamatan peneliti pengembangan keterampilan menulis di Taman Kanak-Kanak perlu ditingkatkan dan dikembangkan lagi melalui permainan yang menarik. Peneliti ingin melibatkan media dalam melatih keterampilan menulis anak usia dini. Media yang akan digunakan peneliti adalah puzzle. Dimana anak dapat bermain menggunakan puzzle dengan menyusun potongan gambar menjadi satu. Puzzle tersebut berisikan satu gambar.

Puzzle menurut Fadlillah, (2017:112) merupakan bentuk permainan modern yang dimainkan dengan cara menyusun potongan gambar menjadi satu, sehingga sesuai gambar aslinya atau sesuai yang diinginkan.

Sedangkan Herawati (dalam Jurnal Ananda, 2019:30) menjelaskan puzzle merupakan sejenis permainan yang berupa potongan-potongan gambar yang cara bermainnya yaitu dengan menyusunnya sehingga terbentuk sebuah gambar, dengan tujuan untuk melatih kesabaran, memudahkan peserta didik dalam memahami konsep, memecahkan masalah, saling bekerja sama dengan teman, serta mengembangkan keterampilan motorik dan kognitif murid.

Pada dasarnya permainan puzzle ini sudah sering dijumpai di Taman Kanak-Kanak. Namun peneliti membuat permainan puzzle ini semakin memiliki tantangan tersendiri bagi anak, yaitu anak tidak hanya diberi tugas untuk menyusun puzzle saja, tetapi anak juga menuliskan kata yang sesuai dengan gambar yang ada pada puzzle tersebut di lembar kertas yang telah disediakan. Dengan demikian tidak hanya bermain namun anak juga dilatih dalam keterampilan menulisnya.

\section{METODE PENELITIAN}

Berdasarkan judul di atas, maka jenis penelitian ini adalah penelitian kuantitatif. Penelitian ini menggunakan desain Pre- 


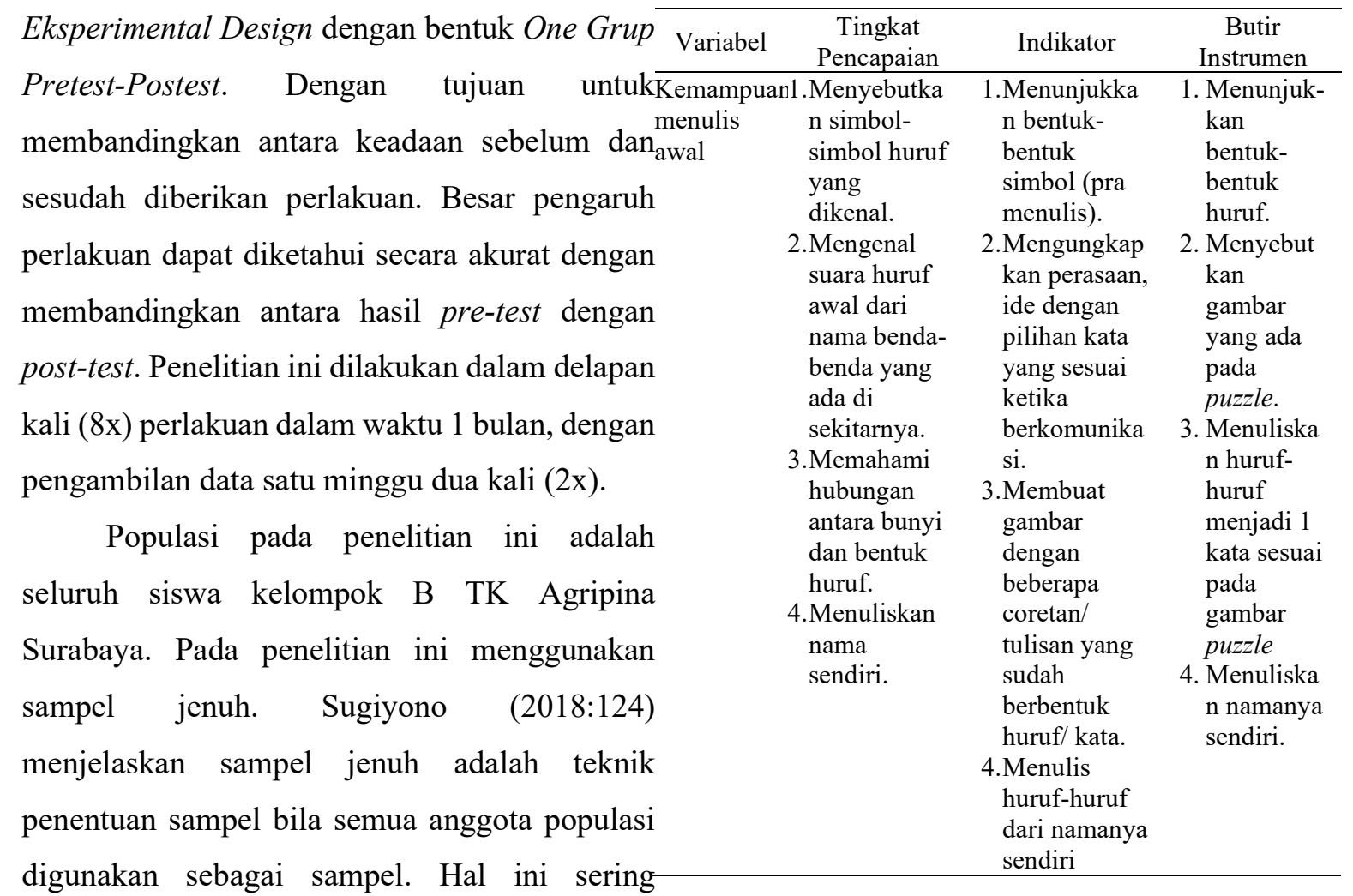
dilakukan bila jumlah populasi relatif kecil, kurang dari 30 orang, atau penelitian yang ingin membuat generalisasi dengan keseluruhan yang sangat kecil. Pada penelitian ini kelompok B TK Agripina Surabaya sebanyak 20 anak dijadikan sebagai sampel.

Instrumen penelitian ini adalah lembar observasi kinerja. Lembar observasi kinerja digunakan untuk mengukur kemampuan menulis awal anak dalam program pengembangan bahasa. Lembar observasi kinerja digunakan sebelum dan sesudah perlakuan untuk memperoleh data mengenai kemampuan menulis awal anak. Berikut kisi-kisi instrumen kemampuan menulis awal anak kelompok B TK Agripina Surabaya sebagai berikut.

Instrumen tingkat

pencapaian perkembangan kemampuan menulis awal anak di atas disesuaikan berdasarkan Peraturan Menteri dan Kebudayaan Republik Indonesia Nomor 137 Tahun 2014, sedangkan indikator diperoleh berdasarkan Peraturan Menteri dan Kebudayaan Republik Indonesia Nomor 146 Tahun 2014.

Teknik pengumpulan data yang digunakan dalam penelitian ini adalah observasi partisipatif di mana peneliti terlibat langsung dalam kegiatan yang dilakukan oleh anak. Selain melakukan observasi partisipatif, peneliti juga menggunakan dokumentasi sebagai penunjang metode pengambilan data dalam penelitian ini.

Data dianalisis dengan teknik analisis uji $t$

Tabel 1. Tingkat Pencapaian Perkembangan Kemampuan Menulis Awal Anak

untuk menguji perbedaan hasil pre test dan post test dari setiap perlakuan. Teknik analisis uji diterapkan dalam penelitian ini karena sesuai 
dengan desain penelitian yang telah ditetapkan.

Rumus adalah uji t yang digunakan adalah:

$$
t=\frac{M d}{\sqrt{\frac{\sum X^{2} d}{N(N-1)}}}
$$

Keterangan :

Md : Mean dari deviasi (d) antara post-test dan pre-test

Xd : Perbedaan deviasi dengan mean deviasi

$\mathrm{N}$ : Banyaknya subyek

Df : db adalah N-1

\section{HASIL PENELITIAN}

Rekapitulasi data hasil pre test dan post test dipaparkan dalam bentuk tabel yang selanjutnya dilakukan uji hipotesis, kemudian dicari hasil uji perbedaan rerata antara pre test dan post test. Data ini akan digunakan untuk melakukan uji hipotesis untuk menentukan nilai indeks signifikansi $t$-test $\left(\mathrm{t}_{\text {hitung }}\right)$. Adapun hasil penelitian disajikan dalam bentuk tabel sebagai berikut.

Tabel 2. Perbedaan Rerata Hasil Pre Test-Post Test

\begin{tabular}{cccc} 
Sulbyek & Pre-Test & Pest-Test & Gain \\
\hline 1 & 2.47 & 2.75 & 0.28 \\
2 & 2.06 & 2.75 & 0.69 \\
3 & 2.22 & 3.00 & 0.79 \\
4 & 1.94 & 2.53 & 0.59 \\
5 & 2.31 & 2.72 & 0.41 \\
6 & 2.50 & 2.75 & 0.25 \\
7 & 2.06 & 2.69 & 0.63 \\
8 & 2.19 & 2.50 & 0.31 \\
9 & 1.31 & 2.50 & 0.69 \\
10 & 2.13 & 2.50 & 0.38 \\
11 & 2.25 & 2.50 & 0.25 \\
12 & 2.94 & 3.00 & 0.06 \\
13 & 2.50 & 2.75 & 0.75 \\
14 & 2.38 & 2.69 & 0.31 \\
15 & 2.88 & 3.00 & 0.13 \\
16 & 2.38 & 2.75 & 0.38 \\
17 & 2.00 & 2.25 & 0.75 \\
18 & 2.19 & 2.75 & 0.56 \\
19 & 2.00 & 2.44 & 0.44 \\
20 & 2.25 & 3.00 & 0.75 \\
20 & 45.44 & 53.81 & 8.39 \\
Jumlah & 2.27 & 1.18 & 16.75 \\
\hline
\end{tabular}

Untuk keperluan uji hipotesis dalam menentukan nilai t-test ( $\mathrm{T}_{\text {hitung }}$ ) dibutuhakan tabel berikut.

Tabel 3. Tabel Persiapan Uji Hipotesis

\begin{tabular}{cccc} 
Subyok & $d$ & $x_{d}=[d-M d)$ & $x_{d}^{2}$ \\
\hline 1 & 0.28 & -0.14 & 0.02 \\
2 & 0.69 & 0.27 & 0.07 \\
3 & 0.78 & 0.36 & 0.13 \\
4 & 0.59 & 0.18 & 0.09 \\
5 & 0.41 & -0.01 & 0.00 \\
6 & 0.25 & -0.17 & 0.03 \\
7 & 0.63 & 0.21 & 0.04 \\
5 & 0.31 & -0.11 & 0.01 \\
9 & 0.69 & 0.27 & 0.07 \\
10 & 0.38 & -0.04 & 0.00 \\
11 & 0.25 & -0.17 & 0.09 \\
12 & 0.06 & -0.36 & 0.13 \\
13 & 0.25 & -0.17 & 0.03 \\
14 & 0.31 & -0.11 & 0.01 \\
15 & 0.13 & -0.29 & 0.09 \\
16 & 0.38 & -0.04 & 0.00 \\
17 & 0.25 & -0.17 & 0.03 \\
18 & 0.56 & 0.14 & 0.02 \\
19 & 0.44 & 0.012 & 0.00 \\
20 & 0.75 & 0.33 & 0.11 \\
Jumlah & 8.38 & 0.00 & 0.85 \\
& & &
\end{tabular}

Dari tabel 3 di atas dapat diketahui:

$\Sigma \mathrm{d}=8,38$

$\mathrm{N}=20$

$\mathrm{Md}=\frac{\Sigma d}{N}=\frac{8,38}{20}=0,42$

Data tersebut digunakan untuk melakukan uji hipotesis One Group Pre TestPost Test, diperoleh $\mathrm{t}_{\text {hitung }}$ sebesar 8,40

Ringkasan hasil analisis uji hipotesis di atas sebagai berikut.

Tabel 4. Ringkasan Hasil Uji Hipotesis 


\begin{tabular}{|c|c|c|c|c|c|}
\hline 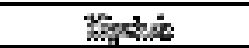 & 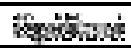 & $y_{0,2}$ & $\Delta s$ & 悹 & 然 \\
\hline 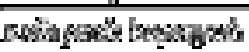 & \क & 26. & 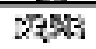 & diats: & 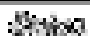 \\
\hline 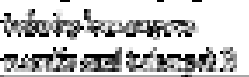 & 2 2x. & & 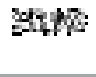 & & \\
\hline
\end{tabular}

Dari tabel di atas dapat diketahui bahwa nilai $t_{\text {tabel }}$ lebih kecil daripada nilai $t_{\text {hitung }}$ baik pada taraf signifikansi 0,05 maupun pada taraf signifikansi 0,01. Dengan demikian Hipotesis Nol ditolak sehingga Hipotesis Kerja diterima. Dari tabel tersebut juga dapat diketahui bahwa nilai $\mathrm{t}$ hitung lebih besar daripada nilai $\mathrm{t}$ tabel pada kedua taraf signifikansi itu, maka dapat dikatakan bahwa Hipotesis Kerja terbukti secara signifikan. Dengan demikian dapat dikatakan bahwa media puzzle berpengaruh pada kemampuan menulis awal peserta didik kelompok B TK Agripina.

\section{PEMBAHASAN}

Dari hasil penelitian dapat diketahui bahwa nilai t hitung lebih besar daripada nilai $t$ tabel pada kedua taraf signifikansi 0,05 dan 0,01 maka dapat dikatakan bahwa Hipotesis Kerja terbukti secara signifikan. Dengan demikian dapat dikatakan bahwa media puzzle berpengaruh pada kemampuan menulis awal peserta didik kelompok B TK Agripina.

Bermain dengan media puzzle anak-anak tidak hanya mendapatkan kesenangan dalam bermain, namun juga memberikan kesempatan pada anak untuk mengembangkan aspek bahasanya terutama pada kemampuan menulisnya. Terbukti ketika memainkan puzzle anak-anak merespon dengan menyebutkan gambar yang ada pada puzzle, selain itu anak juga dapat menuliskan kata dengan menuliskan huruf-huruf yang tepat sesuai gambar pada puzzle. Dengan kata lain media puzzle memiliki pengaruh terhadap kemampuan keaksaraan anak sesuai dengan hasil penelitian yang dilakukan oleh Ifanah (2016) yang menegaskan bahwa ada pengaruh media permainan puzzle huruf terhadap kemampuan keaksaraan anak.

Setelah anak melakukan kegiatan bermain dengan media puzzle, anak justru memiliki tantangan untuk mencoba dan mencoba lagi dalam memainkan puzzle. Karena dalam permainan puzzle ini tidak hanya aspek bahasa saja yang dikembangkan namun juga melibatkan aspek kognitif anak, dimana aspek kognitif dapat dilihat dari bagaimana anak menyusun puzzle menjadi 1 keutuhan yang utuh. Seperti penelitian yang dilakukan oleh Gita (2017) yang menyimpulkan bahwa permainan puzzle dapat mempengaruhi perkembangan kognitif anak.

Hasil dari peneliti setelah penerapan kegiatan dengan media puzzle anak mulai mau menulis, menulis tanpa bantuan dari orang dewasa, dan hasil tulisan sudah sempurna, anak sudah mengetahui cara menulis huruf yang benar.

Bukti adanya pengaruh media puzzle terhadap kemampuan menulis awal kelompok B TK Agripina Surabaya ditujukan oleh hasil analisis data bahwa $t_{\text {hitung }}$ sebesar 8,40 lebih besar dari $t_{\text {tabel }} 1,72913$ pada taraf signifikansi 0,05 maupun 2,53948 pada taraf signifikansi 0,01. Adapun grafik perbedaan rata-rata hasil pre test dan post test. 


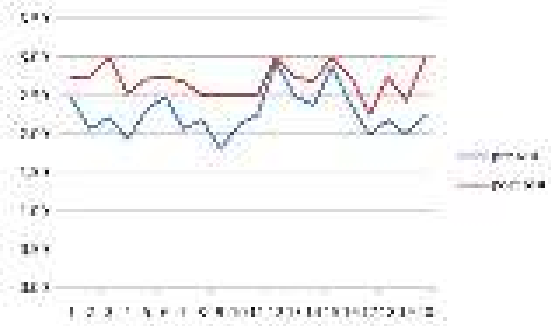

Gambar 1. Grafik Perbedaan rerata hasil pre testpost test

Dapat dilihat pada grafik di atas bahwa terjadi perbedaan sebelum diberikan perlakuan (pre test) dan sesudah diberikan perlakuan (Post test). Hal ini menunjukkan bahwa media puzzle berpengaruh sangat signifikansi pada kemampuan menulis awal kelompok B TK Agripina Surabaya.

\section{A. SIMPULAN DAN SARAN}

\section{Simpulan}

Dapat dilihat berdasarkan hasil hipotesis dan pembahasan hasil penelitian yang berpijak pada rumusan masalah "apakah media puzzle berpengaruh terhadap kemampuan menulis awal kelompok B TK Agripina Surabaya, maka disimpulkan bahwa "Media Puzzle Berpengaruh Terhadap Kemampuan Menulis Awal Kelompok B TK Agripina Surabaya"

\section{SIMPULAN DAN SARAN}

\subsection{Simpulan}

Berdasarkan hasil hipotesis dan pembahasan hasil penelitian yang berpijak pada rumusan masalah "apakah media puzzle berpengaruh terhadap kemampuan menulis awal kelompok B TK Agripina Surabaya, maka disimpulkan bahwa "Media Puzzle Berpengaruh Terhadap Kemampuan Menulis Awal Kelompok B TK Agripina Surabaya"

\subsection{Saran}

Berdasarkan simpulan penelitian ini, bahwa media puzzle berpengaruh pada kemampuan menulis awal kelompok B TK Agripina Surabaya, maka dapat disarankan kepada:

\section{a. Guru}

Permainan dengan media puzzle memiliki pengaruh besar terhadap perkembangan bahasa anak kelompok B TK Agripina Surabaya terutama pada keaksaraannya yaitu menulis awal. Oleh karena itu, diharapkan guru mengaplikasikan permainan dengan menggunakan media puzzle dalam kegiatan belajar mengajar di sekolah sehingga dapat membantu dalam mengoptimalkan kemampuan menulis awal bagi peserta didik.

b. Sekolah

Sekolah diharapkan menyediakan sarana pembelajaran atau APE (Alat Permainan Edukatif) yang menunjang keberhasilan peserta didik dalam belajar yang berkaitan dengan perkembangan kemampuan menulis awal bagi peserta didik salah satunya media puzzle.

c. Orang Tua

Orang tua juga diharapkan menyediakan media pembelajaran di rumah sebagai sarana penunjang belajar anak agar kemampuan menulis anak dapat tersalurkan. Selain itu orang tua juga perlu memberikan dukungan dan motivasi dalam setiap kegiatan belajar maupun bermain. Permainan hendaknya diarahkan kepada hal yang bersifat edukatif.

d. Peneliti

Bagi para peneliti selanjutnya diharapkan dapat melakukan penelitian yang lebih lanjut dengan teknik penelitian yang lebih variatif mengenai perkembangan kemampuan menulis awal anak melalui berbagai permainan.

\section{REFERENSI}

Ananda, Yuanita (2019). Pengaruh Terapi Bermain Puzzle Terhadap Perkembangan Motorik Halus Pada Anak Pra Sekolah Di TK Inti Gugus Tulip III Padang Tahun 2018. Jurnal Keperawatan Abdurrab Volume 2 No 2. Online. https://jurnal.univrab.ac.id. Diakses pada 27 Juli 2019.

Departemen Pendidikan dan Kebudayaan (2014). Peraturan Menteri Pendidikan dan Kebudayaan Republik Indonesia Nomor 
137 Tahun 2014 Tentang Standar Nasional Pendidikan Anak Usia Dini.

Departemen Pendidikan dan Kebudayaan (2014). Peraturan Menteri Pendidikan dan Kebudayaan Republik Indonesia Nomor 146 Tahun 2014 Tentang Kurikulum 2013 Pendidikan Anak Usia Dini.

Dewi, Dian Puspa\& Fachrurazi, Ahmad (2014). Konsep Dasar Pendidikan Anak Usia Dini. Surabaya: Adi Buana University Press.

Dhieni, Nurbiana (2015). Metode Pengembangan Bahasa. Tangerang Selatan: Universitas Terbuka.

Fadlillah (2017). Bermain dan Permainan Anak Usia Dini. Jakarta: Kencana.

Gita, Dinda Yuswara (2017). Publikasi Ilmiah Pengaruh Permainan Puzzle Terhadap Perkembangan Kognitif Anak Kelompok B Di TK Negeri Pembina Manyaran Tahun Ajaran 2016/2017. Surakarta: Universitas Muhammadiyah. Online. https://eprints.ums.ac.id. Diakses pada 27 Juli 2019.

Gunarti, Winda dkk. (2015). Metode Pengembangan Perilaku dan Kemampuan Dasar Anak Usia Dini. Tangerang Selatan: Universitas Terbuka.

Halimah, Leli (2016). Pengembangan Kurikulum Pendidikan Anak Usia Dini Inspirasi Untuk Pelaksanaan Kurikulum 2013 PAUD. Bandung: PT Refika Aditama.

Ifanah, Evi (2016). Pengaruh Media Permainan Puzzle Huruf Terhadap Kemampuan Keaksaraan Anak Kelompok A. Jurnal PAUD Teratai Volume 05 No 02. Online. https://jurnalmahasiswa.unesa.ac.id. Diakses pada 27 Juli 2019.

Madyawati, Lilis (2017). Strategi Pengembangan Bahasa Pada Anak. Jakarta: Kencana.

Masnipal (2018). Menjadi Guru PAUD Profesional. Bandung: PT Remaja Rosdakarya.

Mulyani, Novi (2016). Dasar-Dasar Pendidikan Anak Usia Dini. Yogyakarta: Kalimedia.

Mulyasa (2014). Manajemen PAUD. Bandung: PT Remaja Rosdakarya.

Mulyati, Yeti (2014). Keterampilan Berbahasa Indonesia SD. Tangerang Selatan: Universitas Terbuka.
Sugiyono (2018). Metode Penelitian Pendidikan Pendekatan Kuantitatif, Kualitatif, dan R\&D. Bandung: Alfabeta.

Susanto, Ahmad (2017). Pendidikan Anak Usia Dini (Konsep dan Teori). Jakarta: PT Bumi Aksara. 